\title{
Assessing the value of annual and perennial forage mixtures for bumblebees by direct observation and pollen analysis ${ }^{1}$
}

\author{
Claire CARVELL ${ }^{\mathrm{a}, \mathrm{b} *}$, Paul WESTRICH ${ }^{\mathrm{c}}$, William R. MEEK ${ }^{\mathrm{a}}$, Richard F. PYWELL ${ }^{\mathrm{a}}$, \\ Marek NOWAKOWSKI ${ }^{\mathrm{d}}$
}

\begin{abstract}
a NERC Centre for Ecology and Hydrology, Monks Wood, Abbots Ripton, Huntingdon, PE28 2LS, UK b School of Biological Sciences, University of Southampton, Bassett Crescent East, Southampton SO16 7PX, UK c Lichtensteinstr. 17, 72127 Kusterdingen, Germany

d The Farmed Environment Company, Manor Farm, Eddlethorpe, North Yorkshire YO17 9QT, UK
\end{abstract}

Received 28 September 2004 - revised 15 April 2005 - accepted 22 August 2005

\begin{abstract}
The value of introduced seed mixtures in providing forage for bumblebees on farmland was assessed by direct observation of individuals and analysis of pollen loads. Two mixtures of perennial grasses and wildflowers were compared with an annual mix of mostly seed-bearing crops over three years. Foraging bees showed contrasting patterns of visitation depending on species. Longer-tongued Bombus species preferred the perennial mixtures in which Trifolium pratense was dominant, whilst shorter-tongued Bombus and honeybees, Apis mellifera, visited mainly Borago officinalis in the annual mix. These patterns were supported by analysis of pollen loads from B. pascuorum and B. terrestris, both species showing a high degree of flower constancy to sown species. The relative specialisation of different bee species towards certain plant families, and the flowering phenology of seed mix components, must be considered in the design of agri-environment measures to conserve these and other pollinators.
\end{abstract}

bumblebees / foraging / pollen / seed mixture / restoration / Bombus

\section{INTRODUCTION}

Bumblebees (Bombus spp.) provide an essential pollination service for many entomophilous crops and wild flowers, and are therefore an integral component of agricultural and semi-natural ecosystems (Kevan, 1991; Free, 1993). However, evidence suggests that bumblebees have declined dramatically across Europe and North America in recent decades (Rasmont and Mersch, 1988; Kosior, 1995; Buchmann and Nabhan, 1996). Of the assemblage of 25 Bombus species in the UK, three species have become extinct and several more have shown marked contractions in range, four of which are on the UK Biodiversity Action Plan as priorities for conservation (Williams, 1982; Anon., 1995). These declines are thought to be largely due to the intensification of agriculture, which has also affected many other wild pollinators (Kevan, 1991). Changes in land use and agricultural practices have resulted in the loss of both nesting and foraging habitats, in particular the abundance of key forage plant species associated with semi-natural habitats (Fuller, 1987; Corbet et al., 1991; Haines-Young, 2000). Thus, there is an urgent need to restore and maintain habitats of value for bumblebees and other pollinating insects in intensively managed agricultural landscapes. This has been recognised at a global level by the launch of the International Pollinator Initiative (Dias et al., 1999).

Although they can be seen on a number of different flowers, many bumblebee species preferentially visit perennials from the Fabaceae,

\footnotetext{
* Corresponding author: ccar@ceh.ac.uk

${ }^{1}$ Manuscript editor: Bernard Vaissière
} 
Lamiaceae and Asteraceae such as Trifolium pratense, Lamium album and Centaurea nigra (eg. Fussell and Corbet, 1992; Goulson and Darvill, 2004). The flowers of certain annuals such as Borago officinalis (borage), Centaurea cyanus (cornflower), and Raphanus sativus (fodder radish) can also be attractive to some species (Carreck et al., 1999). Recent developments in European agri-environmental policy have encouraged the introduction of such species to uncropped areas on farmland (Marshall and Moonen, 2002). For example, in England, legumes (Fabaceae) have been recommended as components of a new option for arable land under the Environmental Stewardship Scheme, referred to as the 'pollen and nectar flower mixture'. Annual species, such as R. sativus, are often included in mixtures of seed-bearing crops under the 'wild bird seed mixture' option to provide winter food and cover for farmland birds (http://www.defra.gov.uk/erdp/schemes/ es/default.htm).

Uncropped field margins sown with perennial wildflower mixtures have been shown to significantly enhance the abundance and diversity of nectar- and pollen-feeding insects compared with margins sown with tussocky grass mixtures, conventional crops, treated as conservation headlands or ploughed and left to regenerate naturally (Meek et al., 2002; Carvell et al., 2004; Pywell et al., 2005). However, the flowering component of these mixtures has not been specifically designed to provide the range and succession of forage plants required by bumblebees (Bombus spp.). Nectar and pollen are required throughout the colony's active period from late April to September, and any gap in flowering due to management actions or flowering phenology in components of the sown mixture could be detrimental to colony development. In addition, bumblebees have varying tongue lengths depending on species which, amongst other factors, determine their preferences for certain forage plants (Pyke, 1982; Prŷs-Jones and Corbet, 1991). Within species the different sexes may also visit different flowers. Therefore conservation of the full bumblebee assemblage (in terms of foraging resources) requires a range of flowers from which nectar and pollen are accessible (Ranta and Lundberg, 1980; Harder, 1985).

The aim of this study was to assess the relative value of three contrasting seed mixtures (all available as options under the Environmental Stewardship Scheme) in providing resources for foraging bumblebees on an arable farm. Most studies of foraging bees tend to focus on the flower visits of individuals observed on localised transect walks, and sometimes note whether nectar, pollen, or both are being collected (e.g. Fussell and Corbet, 1992; Goulson and Darvill, 2004). No studies to date have examined the value of restored habitats by analysing the composition of pollen loads collected by foraging workers, although these can give us useful information about the flowers from which they are obtaining pollen, and about their relative importance based on the proportion of species in each sample (e.g. Brian, 1951; Westrich and Schmidt, 1986). Bumblebees require pollen for their reproduction as it is the sole protein source for developing larvae, and recent evidence suggests that adult workers have an ongoing need for pollen throughout their lives (Smeets and Duchateau, 2003). It is therefore important to assess whether newly restored habitats on farmland are providing this resource, if they are to promote conservation of the bumblebee fauna. In this study, we supplemented direct observations of foraging individuals on the three sown mixtures with the collection and analysis of pollen loads from two Bombus species, B. pascuorum and $B$. terrestris/lucorum, to represent both the long- and short-tongued species guilds respectively.

\section{METHODS}

\subsection{Study site and experimental design}

Research was conducted on an intensively managed arable farm of 164 ha, in North Yorkshire, UK (Lat. 54 ${ }^{\circ} 05^{\prime} \mathrm{N}$, Long. $0^{\circ} 49^{\prime} \mathrm{W}$; $40 \mathrm{~m}$ above mean sea level). This is a demonstration farm which aims to show that practical wildlife conservation and profitable farming can be effectively integrated (http:// www.f-e-c.co.uk). Three seed mixtures were sown along the margin of a large arable field on 17th April 2001. Plots were $30 \mathrm{~m}$ long $\times 6 \mathrm{~m}$ wide, each replicated five times following a randomised block design. The treatments comprised two mixtures of native perennial grasses and wildflowers (one 'basic' with three herbaceous species and one 'diverse' with 18 herbs) and one of predominantly seed-bearing cover crops sown annually (Tab. I). In terms of seedbed preparation, plots containing the 
Table I. Seed mixture details (* Wildflower seed was of native lowland UK provenance, purchased from a commercial seed house).

\begin{tabular}{|c|c|c|c|c|c|c|}
\hline Mixture type & & $\begin{array}{l}\text { Basic } \\
\text { perennial } \\
\text { Grass \& } \\
\text { wildflower* }\end{array}$ & $\begin{array}{l}\text { Diverse } \\
\text { perennial } \\
\text { Grass \& } \\
\text { wildflower* }\end{array}$ & Annual cover crop & & \\
\hline Recommended seeding rate & & $37 \mathrm{~kg} / \mathrm{ha}$ & $37 \mathrm{~kg} / \mathrm{ha}$ & $5.5 \mathrm{~kg} / \mathrm{ha}$ & & \\
\hline Scientific name & $\begin{array}{l}\text { Common name } \\
\text { (UK) }\end{array}$ & $\begin{array}{l}\% \\
\text { composition }\end{array}$ & $\begin{array}{l}\% \\
\text { composition }\end{array}$ & Scientific name & $\begin{array}{l}\text { Common name } \\
\text { (UK) }\end{array}$ & $\begin{array}{l}\% \\
\text { composition }\end{array}$ \\
\hline Centaurea cyanus & Cornflower & & 0.2 & Borago officinalis & Borage & 34 \\
\hline Centaurea nigra & Black Knapweed & 2 & 1.5 & Raphanus sativus & Fodder Radish & 22 \\
\hline Daucus carota & Wild Carrot & & 1 & Linum usitatissimum & Linseed & 11 \\
\hline Knautia arvensis & Field Scabious & & 1.5 & Sinapis alba & Mustard & 11 \\
\hline Lathyrus pratensis & Meadow Vetchling & & 0.5 & Melilotus officinalis & Yellow-blossom & 22 \\
\hline Leontodon hispidus & Rough Hawkbit & & 1 & & Clover & \\
\hline Leucanthemum vulgare & Oxeye Daisy & & 2 & & & \\
\hline Linaria vulgaris & Common Toadflax & & 3 & & & \\
\hline Lotus corniculatus & Bird's-foot Trefoil & 3 & 1.5 & & & \\
\hline Odontites verna & Red Bartsia & & 0.2 & & & \\
\hline Ononis spinosa & Spiny Restharrow & & 0.5 & & & \\
\hline Primula veris & Cowslip & & 0.5 & & & \\
\hline Prunella vulgaris & Selfheal & & 0.3 & & & \\
\hline Silene latifolia & White Campion & & 1 & & & \\
\hline Stachys officinalis & Betony & & 1 & & & \\
\hline Ranunculus acris & Meadow Buttercup & & 2.5 & & & \\
\hline Taraxacum officinalis & Dandelion & & 0.5 & & & \\
\hline Trifolium pratense & Red Clover & 15 & 2 & & & \\
\hline Agrostis capillaris & Common Bent & 5 & 5 & & & \\
\hline Cynosurus cristatus & Crested Dogstail & 30 & 30 & & & \\
\hline Festuca rubra ssp commuata & Chewing's Fescue & 10 & 10 & & & \\
\hline Festuca rubra ssp juncea & Slender Red Fescue & 20 & 20 & & & \\
\hline Poa pratensis & Smooth Meadow Gras & 15 & 15 & & & \\
\hline Number of herb species & & 3 & 18 & & & 5 \\
\hline Number of grass species & & 5 & 5 & & & \\
\hline Total No. of species & & 8 & 23 & & & 5 \\
\hline
\end{tabular}

two perennial mixtures were ring rolled (levelled), and those with the annual mixture were ring rolled and harrowed prior to sowing. Subsequent management involved an application of slug pellets and insecticide (to control weevils on the Trifolium pratense) during the second month of establishment. The perennial plots were cut three times during 2001, with the cuttings removed, to ensure successful establishment, and again in early April and late August 2002. The annual treatments were ploughed and re-sown with the same mixture in March 2002 and again in March 2003.

\subsection{Bumblebee activity}

During 2001, bumblebee activity was recorded on 24th and 25th July, to obtain preliminary data on the use of the different mixtures in the establishment year. In 2002, records were made on 12 sampling dates between 28th May and 20th August. In 2003, records were made on 7 dates between 14th May and 11th August. All sampling was conducted between 09:30 and 17:00 $\mathrm{h}$, and during dry weather when the ambient temperature was above $15^{\circ} \mathrm{C}$. On each sampling date, transects were walked along the centre of 
all plots, recording foraging bumblebees and honeybees, and the flower species on which each bee was first seen, within $2 \mathrm{~m}$ to each side of the observer. Bombus terrestris (L.) and B. lucorum (L.) workers cannot always be reliably distinguished in the field (Prŷs-Jones and Corbet, 1991), if considered as two species, so were collectively recorded as $B$. terrestris/lucorum. We refer to this species pair as B. terrestris from here. Males were recorded separately from females for Bombus lapidarius only, as sex separation of other species in the field can be unreliable. The cuckoo bumblebees (subgenus Psithyrus spp. auct.) were recorded together as a group for analysis.

\subsection{Flower abundance}

In order to gain a measure of forage availability and the success in establishment and flowering of sown species, the number of flowers/inflorescences of each plant species present within each plot was estimated using a 5-point scale: $1=1-25$ flowers; 2 = 26-200 flowers; 3 = 201-1000 flowers; 4 = 1001-5000 flowers; $5=>5000$ flowers (as in Carvell et al., 2004). One flower 'unit' was counted as an umbel (e.g. Daucus carota), head (e.g. T. pratense), spike (e.g. Ononis spinosa) or capitulum (e.g. Centaurea nigra). Plant species nomenclature follows Stace (1999). Flower abundance scores were recorded on every sampling date, immediately following bumblebee transects.

\subsection{Collection and analysis of pollen loads}

Pollen loads were collected from two species commonly occurring at the study site; $B$. pascuorum (Scopoli) and B. terrestris, on three dates: 10th, 11th and 12th July 2002, approaching the peak of colony activity in these species (Prŷs-Jones and Corbet, 1991). Within each plot, the first ten workers of either $B$. terrestris or $B$. pascuorum that were observed to be carrying pollen loads were caught. A single complete pollen load was removed from each bee using a fresh cocktail stick, whilst the bee was restrained using a marking cage with soft plunger. The Bombus species, flower species on which it was foraging, plot number and treatment were recorded on a label which was placed with the pollen load in a sample tube, and this was cooled at $5{ }^{\circ} \mathrm{C}$ for preservation prior to analysis. Weather conditions were noted, but remained fine throughout the three sampling days.

All pollen samples were processed by mixing and embedding as a thin layer in glycerine jelly and mounting on a microslide (Westrich and Schmidt, 1986). Samples were analysed using a light microscope to identify (a) the pollen genera and where possible the most likely plant species from which they were collected according to the exine morphology and grain size, and (b) an estimate of the percentage species composition of each pollen load based on a count of 200 grains per sample. Species present in trace amounts comprising less than $1 \%$ of a load were regarded as possible contamination and were excluded from the analysis. Pollen identifications were made with the aid of reference collections and a full list of plant species in flower at the study site during the period of pollen collection. Where the determination of pollen types to species level was not possible, they were identified to species 'group' or plant family level (e.g. Trifolium repens / hybridum).

\subsection{Data analysis}

Bumblebee and honeybee counts were summed for each year to calculate seasonal averages (ie. the mean number observed by direct observation per sample date on each plot). These bumblebee means were log-transformed to stabilise the variance prior to analysis. Flower scores of individual plant species were also summarised as seasonal averages, giving a mean score per plot. To compare the total estimated flower abundance of all species in flower between treatments, species abundance scores were expressed as the median value for each range as follows: Score $1=13$ flowers; $2=113$ flowers; $3=600.5$ flowers; $4=3000.5$ flowers; $5=15000$ flowers. These data were combined into two variables according to whether species had been sown or unsown in the seed mixtures. Differences in bumblebee abundance, flower abundance and species richness (number of species in flower) between the three treatments in each year were tested by two-way ANOVA, including replicates and treatments as factors. Tukey's Honest Significant Difference test was performed on all analyses to assess pairwise differences between the treatments. To examine the possible effects of flower density on differences in bumblebee abundance between treatments, ANCOVAs were performed with 'total number of flowers per plot' (sown and unsown) as the covariate. Changes in flower abundance of key forage species over each sampling season were also examined. Standard deviations on the mean flower scores for each date were calculated as a measure of continuity in forage supply.

The data on pollen load composition were assessed in terms of the total number of species represented within each load (species richness) and the relative proportions of each plant species present. Differences in species richness and percentage of each pollen species per load as sampled from the three treatments were tested by two-way ANOVA, 
Table II. Differences in number of bumblebees, honeybees, mean total number of flowers and richness of species in flower per sampling date on the three seed mixtures in each year (ns, not significant; $* P<0.05$; ** $P<0.01$; *** $P<0.001$; means within a row followed by different letters are significantly different at $P<0.05)$.

\begin{tabular}{|c|c|c|c|c|c|c|}
\hline Year & & $\begin{array}{c}\text { Basic } \\
\text { Perennial }\end{array}$ & $\begin{array}{c}\text { Diverse } \\
\text { Perennial }\end{array}$ & Annual & $\mathbf{F}_{2,8}$ & $\begin{array}{c}\text { ANOVA } \\
\text { Sig. }\end{array}$ \\
\hline 2001 & All bumblebees & $5.1 \mathrm{ab}$ & $3.8 \mathrm{a}$ & $12.5 \mathrm{~b}$ & 5.5 & $*$ \\
\hline \multirow[t]{5}{*}{ (July only) } & Honeybees & $0.0 \mathrm{a}$ & $0.0 \mathrm{a}$ & $17.1 \mathrm{~b}$ & 58.7 & $* * *$ \\
\hline & Total number sown flowers & $2093.5 \mathrm{a}$ & $1578.7 \mathrm{a}$ & $15000.0 \mathrm{~b}$ & 362.1 & $* * *$ \\
\hline & Sown species richness & $2.0 \mathrm{~b}$ & $2.4 \mathrm{~b}$ & $1.0 \mathrm{a}$ & 26.0 & $* * *$ \\
\hline & Total number unsown flowers & $26697.0 \mathrm{~b}$ & $19430.2 \mathrm{~b}$ & $143.0 \mathrm{a}$ & 17.4 & $* * *$ \\
\hline & Unsown species richness & $5.6 \mathrm{~b}$ & $6.4 \mathrm{~b}$ & $3.0 \mathrm{a}$ & 33.9 & $* * *$ \\
\hline 2002 & All bumblebees & $12.6 \mathrm{a}$ & $10.8 \mathrm{a}$ & $24.9 \mathrm{~b}$ & 58.5 & $* * *$ \\
\hline \multirow[t]{5}{*}{ (whole season) } & Honeybees & $0.0 \mathrm{a}$ & $0.0 \mathrm{a}$ & $7.0 \mathrm{~b}$ & 322.9 & $* * *$ \\
\hline & Total number sown flowers & 7540.5 & 6063.5 & 6245.9 & 4.1 & $\mathrm{~ns}$ \\
\hline & Sown species richness & $3.1 \mathrm{~b}$ & $5.2 \mathrm{c}$ & $1.5 \mathrm{a}$ & 499.1 & $* * *$ \\
\hline & Total number unsown flowers & $313.3 \mathrm{ab}$ & $156.2 \mathrm{a}$ & $670.3 \mathrm{~b}$ & 4.7 & $*$ \\
\hline & Unsown species richness & 2.0 & 1.9 & 2.2 & 2.0 & $\mathrm{~ns}$ \\
\hline 2003 & All bumblebees & $16.4 \mathrm{a}$ & $13.3 \mathrm{a}$ & $20.6 \mathrm{~b}$ & 15.6 & $* *$ \\
\hline \multirow[t]{5}{*}{ (whole season) } & Honeybees & $0.2 \mathrm{a}$ & $0.2 \mathrm{a}$ & $4.5 \mathrm{~b}$ & 71.5 & $* * *$ \\
\hline & Total number sown flowers & $5133.2 \mathrm{a}$ & $11030.1 \mathrm{~b}$ & $5274.3 \mathrm{a}$ & 33.9 & $* * *$ \\
\hline & Sown species richness & $3.0 \mathrm{~b}$ & $5.7 \mathrm{c}$ & $0.7 \mathrm{a}$ & 554.2 & $* * *$ \\
\hline & Total number unsown flowers & 122.1 & 79.6 & 215.8 & 0.8 & $\mathrm{~ns}$ \\
\hline & Unsown species richness & 1.4 & 1.3 & 1.6 & 0.4 & ns \\
\hline
\end{tabular}

again with Tukey's test for pairwise differences between treatments.

\section{RESULTS}

\subsection{Flower abundance}

Many species sown in the mixtures established well during their first year (2001; Tab. II). By 2002, all three herb species in plots sown with the basic perennial mix had established, and 12 of the 18 herbs sown in the diverse perennial mix were recorded (though not always in flower). The two perennial treatments contained a significantly higher number of unsown flowers (annuals such as Capsella bursa-pastoris, Matricaria spp. and Myosotis arvensis) than the annual treatment during 2001. This proportion of unsown species decreased in 2002, and flower abundance of sown species increased, with no significant difference between treatments indicating similar flower abundance within each plot (Tab. II). A similar pattern was shown during 2003, although statistical significance was achieved with a higher number of sown flowers in the diverse perennial than basic and annual treatments, as expected from the composition of the seed mixtures.

Flower scores for individual species differed significantly between treatments according to the mixtures in which they were sown (Tab. III). The occurrence of a few flowers in plots where a species was not sown is likely to be due to occasional spread of material, including flower heads, by machinery during cutting at the end of the season. Of the dominant flowering components, red clover, Trifolium pratense had similarly high mean abundance scores in both perennial mixtures, whereas borage, Borago officinalis had mean scores of 2.5 and 1.9 in 2002 and 2003 respectively in the annual mixture. These means (calculated as seasonal averages) are lower than expected given the high density of $B$. officinalis flowers observed, 
Table III. Differences in mean flower abundance scores of sown species per sampling date for the three sown mixtures (treatments) in 2002 and 2003 (figures are in bold where a species was sown; ns, not significant; $* P<0.05$; ** $P<0.01$; *** $P<0.001$; means within a row followed by different letters are significantly different at $P<0.05$ ).

\begin{tabular}{|c|c|c|c|c|c|c|c|c|c|c|}
\hline & & 2002 & & & & & 2003 & & & \\
\hline Sown species & $\begin{array}{c}\text { Basic } \\
\text { Perennial }\end{array}$ & $\begin{array}{c}\text { Diverse } \\
\text { Perennial }\end{array}$ & Annual & $\mathbf{F}_{2,8}$ & $\begin{array}{c}\text { ANOVA } \\
\text { Sig. } 2002 \\
\end{array}$ & $\begin{array}{c}\text { Basic } \\
\text { Perennial }\end{array}$ & $\begin{array}{c}\text { Diverse } \\
\text { Perennial } \\
\end{array}$ & Annual & $\mathbf{F}_{2,8}$ & $\begin{array}{l}\text { ANOVA } \\
\text { Sig. } 2003\end{array}$ \\
\hline Borago officinalis & $0.00 \mathrm{a}$ & $0.00 \mathrm{a}$ & $2.50 \mathrm{~b}$ & 1800.0 & $* * *$ & $0.00 \mathrm{a}$ & $0.00 \mathrm{a}$ & $1.91 \mathrm{~b}$ & 1122.3 & $* * *$ \\
\hline Centaurea nigra & $0.65 \mathrm{~b}$ & $0.58 \mathrm{~b}$ & $0.00 \mathrm{a}$ & 230.2 & $* * *$ & $1.03 \mathrm{~b}$ & $1.09 \mathrm{~b}$ & $0.00 \mathrm{a}$ & 686.0 & $* * *$ \\
\hline Daucus carota & $0.02 \mathrm{a}$ & $0.88 \mathrm{~b}$ & $0.00 \mathrm{a}$ & 93.5 & $* * *$ & $0.03 \mathrm{a}$ & $0.83 \mathrm{~b}$ & $0.00 \mathrm{a}$ & 69.2 & $* * *$ \\
\hline Knautia arvensis & $0.00 \mathrm{a}$ & $0.12 \mathrm{~b}$ & $0.00 \mathrm{a}$ & 5.4 & $*$ & $0.00 \mathrm{a}$ & $0.26 \mathrm{~b}$ & $0.00 \mathrm{a}$ & 13.5 & $* *$ \\
\hline Lathyrus pratensis & $0.00 \mathrm{a}$ & $0.10 \mathrm{~b}$ & $0.00 \mathrm{a}$ & 6.0 & $*$ & $0.00 \mathrm{a}$ & $0.80 \mathrm{~b}$ & $0.00 \mathrm{a}$ & 120.6 & $* * *$ \\
\hline Leucanthemum vulgare & $0.15 \mathrm{a}$ & $2.15 \mathrm{~b}$ & $0.00 \mathrm{a}$ & 312.8 & $* * *$ & $0.00 \mathrm{a}$ & $2.66 \mathrm{~b}$ & $0.00 \mathrm{a}$ & 455.2 & $* * *$ \\
\hline Lotus corniculatus & $1.87 \mathrm{~b}$ & $1.90 \mathrm{~b}$ & $0.02 \mathrm{a}$ & 131.0 & $* * *$ & $2.46 \mathrm{~b}$ & $2.54 \mathrm{~b}$ & $0.00 \mathrm{a}$ & 1393.3 & $* * *$ \\
\hline Melilotus officinalis & $0.00 \mathrm{a}$ & $0.00 \mathrm{a}$ & $0.65 b$ & 9.9 & $* *$ & 0.00 & 0.00 & 0.11 & 4.6 & $*$ \\
\hline Ononis spinosa & $0.00 \mathrm{a}$ & $0.60 \mathrm{~b}$ & $0.00 \mathrm{a}$ & 152.5 & $* * *$ & $0.00 \mathrm{a}$ & $0.83 \mathrm{~b}$ & $0.00 \mathrm{a}$ & 841.0 & $* * *$ \\
\hline Plantago lanceolata & $0.67 \mathrm{~b}$ & $1.13 \mathrm{c}$ & $0.05 \mathrm{a}$ & 59.1 & $* * *$ & $0.89 \mathrm{~b}$ & $1.29 \mathrm{c}$ & $0.00 \mathrm{a}$ & 99.4 & $* * *$ \\
\hline Prunella vulgaris & $0.03 \mathrm{a}$ & $0.38 \mathrm{~b}$ & $0.00 \mathrm{a}$ & 51.3 & $* * *$ & $0.00 \mathrm{a}$ & $0.26 \mathrm{~b}$ & $0.00 \mathrm{a}$ & 23.1 & $* * *$ \\
\hline Raphanus sativus & $0.03 \mathrm{a}$ & $0.00 \mathrm{a}$ & $1.00 \mathrm{~b}$ & 71.1 & $* * *$ & $0.00 \mathrm{a}$ & $0.00 \mathrm{a}$ & $1.57 \mathrm{~b}$ & 93.1 & $* * *$ \\
\hline Silene latifolia & $0.28 \mathrm{~b}$ & $0.20 \mathrm{ab}$ & $0.05 \mathrm{a}$ & 6.1 & $*$ & $0.29 \mathrm{~b}$ & $0.09 \mathrm{ab}$ & $0.00 \mathrm{a}$ & 6.2 & $*$ \\
\hline Sinapis alba & $0.02 \mathrm{a}$ & $0.00 \mathrm{a}$ & $1.42 \mathrm{~b}$ & 80.7 & $* * *$ & $0.00 \mathrm{a}$ & $0.00 \mathrm{a}$ & $1.14 \mathrm{~b}$ & 213.3 & $* * *$ \\
\hline Trifolium pratense & $4.15 \mathrm{~b}$ & $3.97 \mathrm{~b}$ & $0.08 \mathrm{a}$ & 1156.8 & $* * *$ & $3.09 \mathrm{~b}$ & $3.09 \mathrm{~b}$ & $0.00 \mathrm{a}$ & 1138.0 & $* * *$ \\
\hline
\end{tabular}

but are explained by changes in flower abundance over each sampling season (Fig. 2). $T$. pratense flowers were relatively abundant on all sampling visits from late May to August, with a relatively low standard deviation on the mean scores per plot for each year indicating a continuous forage supply $(2002=0.7,2003=$ 1.4). B. officinalis only began flowering around late June, and the results suggest a decrease in flowering towards the end of August, with higher standard deviations than $T$. pratense $(2002=2.1,2003=2.0)$.

Climatic conditions within the region of the study site (Northeast England) were relatively stable during the study, with average yearly temperatures of $8.9^{\circ} \mathrm{C}, 9.5^{\circ} \mathrm{C}$ and $9.6^{\circ} \mathrm{C}$ and a total rainfall of $786 \mathrm{~mm}, 905 \mathrm{~mm}$ and $616 \mathrm{~mm}$ in 2001, 2002 and 2003 respectively (http:// www.metoffice.com/climate/uk/). These patterns were similar to the UK average, perhaps with the exception of a lower rainfall during the winter of 2001-2002. This had no apparent detrimental effect on establishment of the seed mixtures.

\subsection{Bumblebee abundance}

Six social Bombus species were recorded, representing the assemblage most commonly found in the UK. There were significant differences in the total number of bumblebees (altogether 4925 individuals) visiting the three mixtures in all sampling years (see Tab. II). Abundance was highest on the annually sown mixtures in each year, with numbers in the perennial treatments increasing as the mixtures established. Honeybees were restricted almost entirely to the annual mixture, although numbers fell in 2002 and 2003 (hive density in the surrounding landscape was not recorded). Abundance of each Bombus species differed significantly between treatments (Fig. 1). While B. terrestris/lucorum, and B. pratorum (shortertongued species) and honeybees visited the annual mixture almost exclusively, $B$. lapidarius (also a relatively short-tongued species) visited all mixtures and was the most commonly recorded species. B. pascuorum and B. hortorum (longer-tongued species) preferred the two perennial treatments, but there were no 

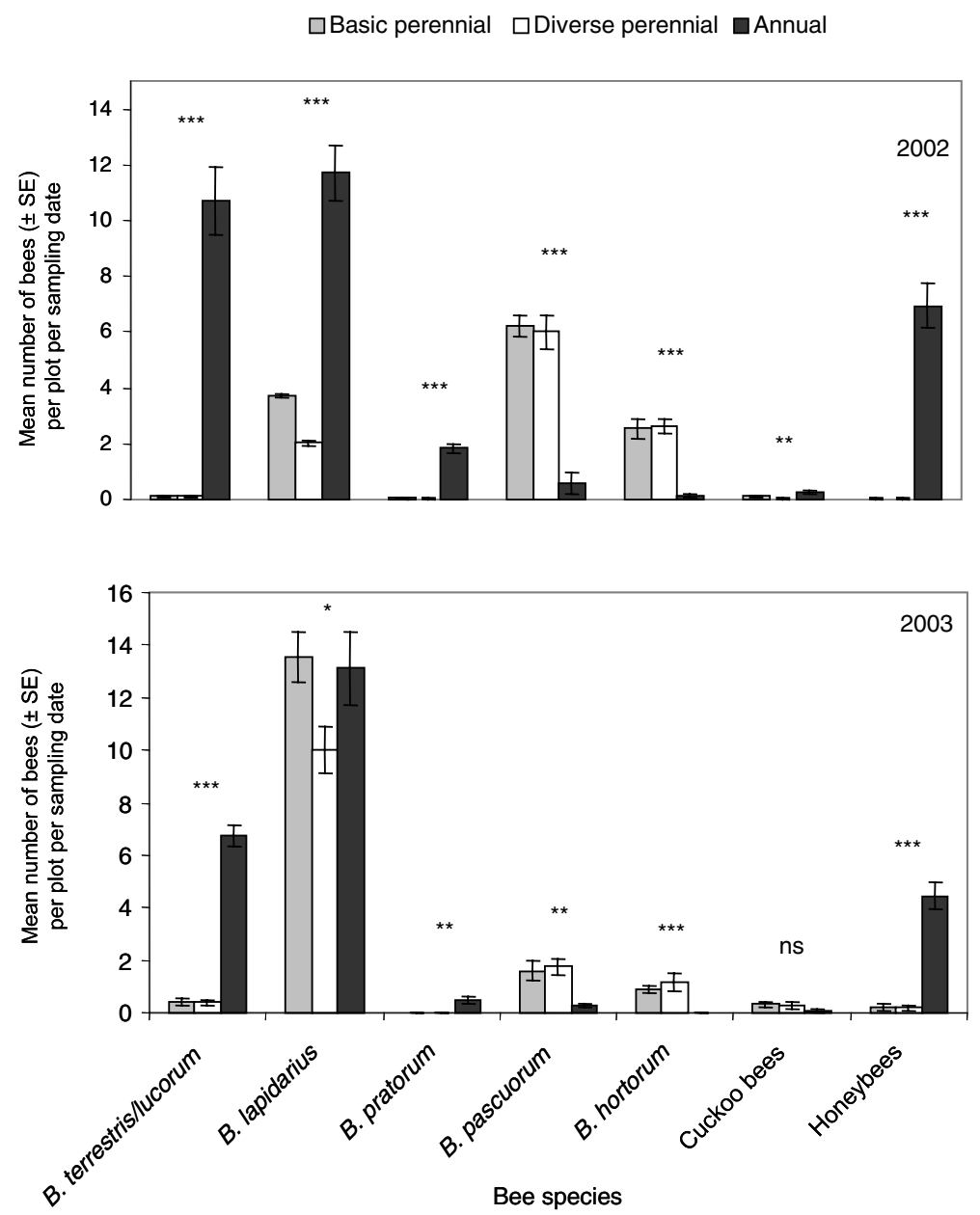

Figure 1. Abundance of different bumblebee species and honeybees on each forage mixture in 2002 and 2003. Treatment differences are shown above each species as follows (ANOVA, $\mathrm{df}=2,8$ ); ns, not significant; * $P<0.05 ; * * P<0.01 ; * * * P<0.001$.

significant differences between the number of visits to the basic and diverse mixtures. Few cuckoo bumblebees visited the margins, but those that were recorded (Bombus $(P$.) vestalis and Bombus (P.) barbutellus) showed a significant preference for the annual mixture in 2002 only. When the 'total number of flowers per plot' was added as a covariate to the analysis of differences in bumblebee abundance between treatments, there was no significant effect of this covariate, and the treatment differences described above were unaffected. Thus bumblebee abundance was apparently more strongly related to seed mixture composition than total flower abundance.

\subsection{Bee activity}

Patterns of forage plant visitation as recorded by direct observation suggest a preference for Borago officinalis flowers by the shortertongued bumblebees (B. terrestris and B. pratorum) and honeybees, though these visits were restricted mainly to July and August (Tab. IV). The longer-tongued species (B. pascuorum and $B$. hortorum) showed a preference for 
Table IV. Foraging visits of bumblebees and honeybees recorded by direct observation (plant species receiving fewer than 5 visits in both years were excluded; $(\mathrm{s})=$ species sown in the experimental mixtures; Flowering periods refer to presence of flowers across all mixtures for both years in half-months as follows: $5.0=1-15$ May; $5.5=16-31$ May; $6.0=1-15$ June; $6.5=16-30$ June, etc.).

\begin{tabular}{|c|c|c|c|c|c|c|c|c|c|c|c|c|c|}
\hline \multirow[b]{3}{*}{ Forage plant species } & \multicolumn{13}{|c|}{ Bee species (\% of total visits to each plant species across all mixtures and all dates within each year) } \\
\hline & \multirow{2}{*}{$\begin{array}{c}\text { Flowering } \\
\text { period }\end{array}$} & \multicolumn{2}{|c|}{ B. terrestris/luc. } & \multicolumn{2}{|c|}{ B. lapidarius } & \multicolumn{2}{|c|}{ B. pratorum } & \multicolumn{2}{|c|}{ B. pascuorum } & \multicolumn{2}{|c|}{ B. hortorum } & \multicolumn{2}{|c|}{ Honeybees } \\
\hline & & 2002 & 2003 & 2002 & 2003 & 2002 & 2003 & 2002 & 2003 & 2002 & 2003 & 2002 & 2003 \\
\hline Borago officinalis (s) & $6.5-8.5$ & 97.6 & 87.4 & 61.4 & 28.2 & 99.3 & 93.2 & 1.0 & 5.7 & 0.6 & & 98.4 & 57.7 \\
\hline Centaurea nigra (s) & $7.0-8.5$ & 0.2 & 8.0 & 17.4 & 59.1 & & & 2.4 & 9.0 & & 1.4 & & 6.0 \\
\hline Cirsium vulgare & $7.0-8.5$ & 0.3 & 0.8 & 2.4 & 0.7 & & & 0.4 & 0.8 & & & & \\
\hline Lotus corniculatus (s) & $5.5-8.5$ & 0.2 & & 4.3 & 2.4 & & & 0.9 & 27.1 & & & 0.2 & \\
\hline Ononis spinosa (s) & $7.5-8.5$ & & 1.5 & & 0.3 & & & 1.0 & 7.4 & & & & 0.6 \\
\hline Raphanus sativus (s) & $6.0-8.5$ & 0.3 & 1.1 & 4.0 & 6.9 & & 6.2 & 0.8 & 0.8 & 0.3 & & 1.2 & 35.7 \\
\hline Sinapis alba (s) & $6.0-8.5$ & & & 0.6 & & & & & & & & & \\
\hline Trifolium pratense (s) & $5.0-8.5$ & 0.9 & 0.4 & 6.6 & 1.4 & 0.9 & & 92.0 & 45.2 & 99.2 & 98.6 & 0.2 & \\
\hline Trifolium repens & $5.0-8.5$ & 0.6 & 0.8 & 3.3 & 0.9 & & & 1.4 & 4.1 & & & & \\
\hline
\end{tabular}

Trifolium pratense, with visits recorded on all sampling dates from May to August. As suggested by the abundance data, B. lapidarius was intermediate in its flower preferences, visiting a range of species but particularly Centaurea nigra in 2003. More than 50\% of these visits to $C$. nigra were by males. Of the additional species sown in the diverse perennial mixture that were not included in the basic mix, only Ononis spinosa was visited more than five times by foraging bumblebees.

\subsection{Pollen load analysis}

A total of 149 pollen load samples were analysed; 44 from $B$. terrestris and 105 from $B$. pascuorum, this difference being due to the tendency for $B$. terrestris to forage from the annual mixture and $B$. pascuorum from both perennial mixtures. Overall, a high proportion of the pollen collected was from plant species sown in the experimental mixtures (88\% of all loads in $B$. pascuorum and $73 \%$ in $B$. terrestris) rather than from other farm habitats. Borago officinalis and Trifolium pratense were the only two plant species for which the mean percentage per load of pollen differed significantly between the three mixtures. They tended to dominate loads sampled from the mixtures in which they were sown (Tab. V).

The typical composition of pollen loads collected by each bee species revealed contrasting preferences for certain plant species (Tabs. V, VI). B. terrestris loads contained pollen from nine species, but only $32 \%$ of loads were of mixed species. Borago officinalis pollen dominated $70 \%$ of samples, often being the sole pollen type present. Pollens from the unsown species Papaver rhoeas and Rubus fruticosus were also present in some samples, and, where they occurred, constituted up to $90 \%$ or $100 \%$ of the load. In contrast, B. pascuorum loads represented 13 plant species, but contained mainly $T$. pratense pollen, which occupied a significantly higher percentage per load sampled from the perennial than the annual mixtures (Tab. V). Many of these loads were of mixed species (53\%), containing additional pollen from Lathyrus pratensis and the unsown Trifolium repens / hybridum and Stachys sylvatica.

The composition of a bumblebees' pollen load did not always relate to the forage plant species on which it had been caught. Of the seven loads from $B$. pascuorum workers sampled on B. officinalis in the annual mixture, only three were dominated by $B$. officinalis pollen, with others comprising mainly Trifolium species (Tab. V) and one with $90 \%$ Linaria vulgaris pollen. The information on forage plant preferences that was gained from pollen load analysis is compared with that from direct observations during July 2002 in Table VI.

\section{DISCUSSION}

\subsection{Annual and perennial mixtures}

This study confirms that British bumblebee species show marked differences in their 
Table V. Differences in mean species richness of pollen loads and mean \% of B. officinalis and T. pratense pollen per load sampled from the three mixtures in 2002 (ns, not significant; $* P<0.05 ; * * P<0.01$; *** $P<0.001$; Means within a row followed by different letters are significantly different at $P<0.05$ ).

\begin{tabular}{|c|c|c|c|c|c|c|}
\hline & & $\begin{array}{c}\text { Basic } \\
\text { Perennial }\end{array}$ & $\begin{array}{c}\text { Diverse } \\
\text { Perennial }\end{array}$ & Annual & $\mathbf{F}_{2,8}$ & $\begin{array}{c}\text { ANOVA } \\
\text { Sig. }\end{array}$ \\
\hline \multirow[t]{3}{*}{ B. terrestris } & Pollen load species richness & 0.00 & 0.60 & 1.35 & 3.6 & ns \\
\hline & $\%$ Borago officinalis pollen & $0.00 \mathrm{a}$ & $0.00 \mathrm{a}$ & $70.76 \mathrm{~b}$ & 283.6 & $* * *$ \\
\hline & $\%$ Trifolium pratense pollen & 0.00 & 0.00 & 2.22 & 1 & $\mathrm{~ns}$ \\
\hline \multirow[t]{3}{*}{ B. pascuorum } & Pollen load species richness & 1.59 & 1.59 & 2.14 & 0.1 & ns \\
\hline & \% Borago officinalis pollen & $1.02 \mathrm{a}$ & $0.00 \mathrm{a}$ & $42.86 \mathrm{~b}$ & 9.9 & ** \\
\hline & $\%$ Trifolium pratense pollen & $75.53 \mathrm{~b}$ & $85.41 \mathrm{~b}$ & $18.57 \mathrm{a}$ & 22.3 & $* * *$ \\
\hline
\end{tabular}

Table VI. Comparison of forage plant preferences as derived from pollen analysis and direct observation methods. Data represent mean \% per pollen load from July 2002 pollen analysis \pm SE, and $\%$ of visits from direct observations during July 2002 only $((\mathrm{s})=$ species sown in the experimental mixtures).

B. terrestris

B. pascuorum

\begin{tabular}{|c|c|c|c|c|}
\hline Pollen / Forage plant species & $\begin{array}{c}\text { Pollen analysis } \\
\mathrm{n}=44 \text { loads }\end{array}$ & $\begin{array}{c}\text { Direct observation } \\
\mathrm{n}=595 \text { visits }\end{array}$ & $\begin{array}{c}\text { Pollen analysis } \\
\mathrm{n}=105 \text { loads }\end{array}$ & $\begin{array}{l}\text { Direct observation } \\
\mathrm{n}=562 \text { visits }\end{array}$ \\
\hline Borago officinalis (s) & $69.55 \pm 6.26$ & 99.32 & $3.30 \pm 1.58$ & 1.07 \\
\hline Centaurea nigra $(\mathrm{s})$ & & & & 0.18 \\
\hline Chamaenerion angustifolium & & & $0.19 \pm 0.19$ & \\
\hline Cirsium vulgare & $0.02 \pm 0.02$ & & $0.57 \pm 0.35$ & \\
\hline Hypericum spp. & & & $0.38 \pm 0.38$ & \\
\hline Impatiens glandulifera & & & $0.38 \pm 0.38$ & \\
\hline Lathyrus pratensis / Vicia cracca (s) & & & $5.26 \pm 1.64$ & \\
\hline Linaria vulgaris $(\mathrm{s})$ & $0.45 \pm 0.45$ & & $1.54 \pm 0.94$ & \\
\hline Lotus corniculatus (s) & & 0.16 & $1.68 \pm 0.90$ & 0.89 \\
\hline Papaver rhoeas & $10.91 \pm 4.20$ & & & \\
\hline Rubus fruticosus & $11.36 \pm 4.28$ & & $1.84 \pm 1.02$ & \\
\hline Sinapis / Raphanus (s) & $2.02 \pm 1.82$ & & & \\
\hline Stachys sylvatica & $1.36 \pm 1.01$ & & $1.37 \pm 0.57$ & \\
\hline Trifolium pratense $(\mathrm{s})$ & $2.27 \pm 2.27$ & & $75.62 \pm 3.17$ & 96.98 \\
\hline Trifolium repens / hybridum & $0.45 \pm 0.45$ & 0.50 & $6.73 \pm 1.77$ & 0.89 \\
\hline Viola arvensis & & & $0.05 \pm 0.05$ & \\
\hline
\end{tabular}

choice of forage plants and highlights some important factors to be considered in the future management of habitats for bumblebees in agricultural areas. When annual and perennial flower mixtures composed of different species were offered together at the same site patterns of visitation, especially for pollen collection, contrasted between bee species. The mixture comprising annual seed-bearing crops attracted all six Bombus species, but particularly the short-tongued Bombus terrestris/lucorum, and it was virtually the only treatment in which honeybees were recorded. This reflected the abundance of Borago officinalis (borage), which has 
been shown both to dominate within annual mixtures and attract short-tongued bumblebees and honeybees in other studies, along with the non-native species Phacelia tanacetifolia (phacelia) (Williams and Christian, 1991; Carreck et al., 1999; Walther-Hellwig and Frankl, 2000). Additional species sown in the annual mixture (e.g. Linum usitatissimum and Melilotus officinalis) contributed little to flower abundance or bumblebee diversity, so could be excluded from the mix in future or replaced with other nectar rich annuals such as Centaurea cyanus or Vicia sativa which may improve its value for longer-tongued bumblebees. However, the primary function of these annual mixtures as an agri-environmental measure is to provide winter food and cover for seed-eating farmland birds (Stoate et al., 2003). The design of such mixtures could be improved to benefit both groups, by providing winter seed for birds and summer pollen and nectar sources for bumblebees and other pollinators.

Previous observations of foraging bees on Borago officinalis have indicated that it may be visited mainly for nectar and not for pollen (Engels et al., 1994; Carreck and Williams, 1997), hence although agronomically viable in the UK, it may be a less valuable forage species than certain perennials. From our results, this was not the case for the short-tongued $B$. terrestris, as Borago officinalis pollen constituted a large part of its pollen diet. However, pollen sampling was only carried out during a limited period in July, and our counts of flower abundance showed that during both years, B. officinalis flowers were unavailable during May and June, thus restricting bee visitation at these times. This suggests that annual mixtures should either be sown sequentially (Carreck and Williams, 2002) or include a wider range of forage species to benefit bees and other pollinators throughout their individual and colony lifespans. Furthermore, due to its annual nature, this option does not allow the establishment of vegetation suitable as nesting habitat for bumblebees (Svensson et al., 2000).

Treatments containing the perennial mixtures were visited mainly by the two longertongued bumblebee species, Bombus pascuorum and Bombus hortorum. This reflected the large number of Trifolium pratense flowers, particularly in 2002 when the proportion of unsown species in the sward had decreased.
The lower number of these bumblebees recorded on average in 2003 may have been due to the reduction in availability of $T$. pratense flowers from July onwards (Fig. 2) or an increase in forage supply elsewhere within their foraging range, although we cannot account for the latter. Bombus lapidarius also visited the perennial treatments to forage mainly on Centaurea nigra, $T$. pratense and Lotus corniculatus. These patterns generally follow the well documented tendency for bumblebees to utilize flowers with corolla lengths which correspond to their tongue length (e.g. Ranta and Lundberg, 1980; Fussell and Corbet, 1992), with B. lapidarius showing a tendency to be intermediate in its forage preferences between the longer- and shorter-tongued groups (as in Goulson et al., 2005). Furthermore, that $B$. lapidarius males visited $C$. nigra almost exclusively suggests that purely legume-based forage patches may not cater for the requirements of both bumblebee sexes.

The importance of $T$. pratense as a pollen source for $B$. pascuorum was evident in our study, as shown by Brian (1951) in the UK, and Anasiewicz and Warakomska (1977) in Poland. Analyses of pollen loads and the pollen collecting behaviour of the rare long-tongued bumblebee species $B$. sylvarum and $B$. humilis in the UK also revealed a strong preference for pollens from the Fabaceae, particularly Trifolium spp. (Edwards, pers. comm.; Goulson and Darvill, 2004). This may reflect the nutritional quality of Fabaceae pollen for bumblebees, which is yet to be determined. As the need to re-introduce $T$. pratense to farmland areas and enhance bumblebee populations increases, native seed sources are becoming costly and difficult to obtain. Mixtures with agricultural varieties of this and other legume species are currently being tested by the authors alongside other agri-environmental measures within a multi-site experiment, and show potential to benefit the longer-tongued bumblebee assemblage in particular.

In terms of the relative value of the 'basic' and 'diverse' perennial mixtures tested in this study, both the direct foraging observations and pollen data suggest that the additional species in the 'diverse' mixture contributed little to bumblebee activity, at least during the first three years of development. Lathyrus pratensis may be an important component of sown perennial 

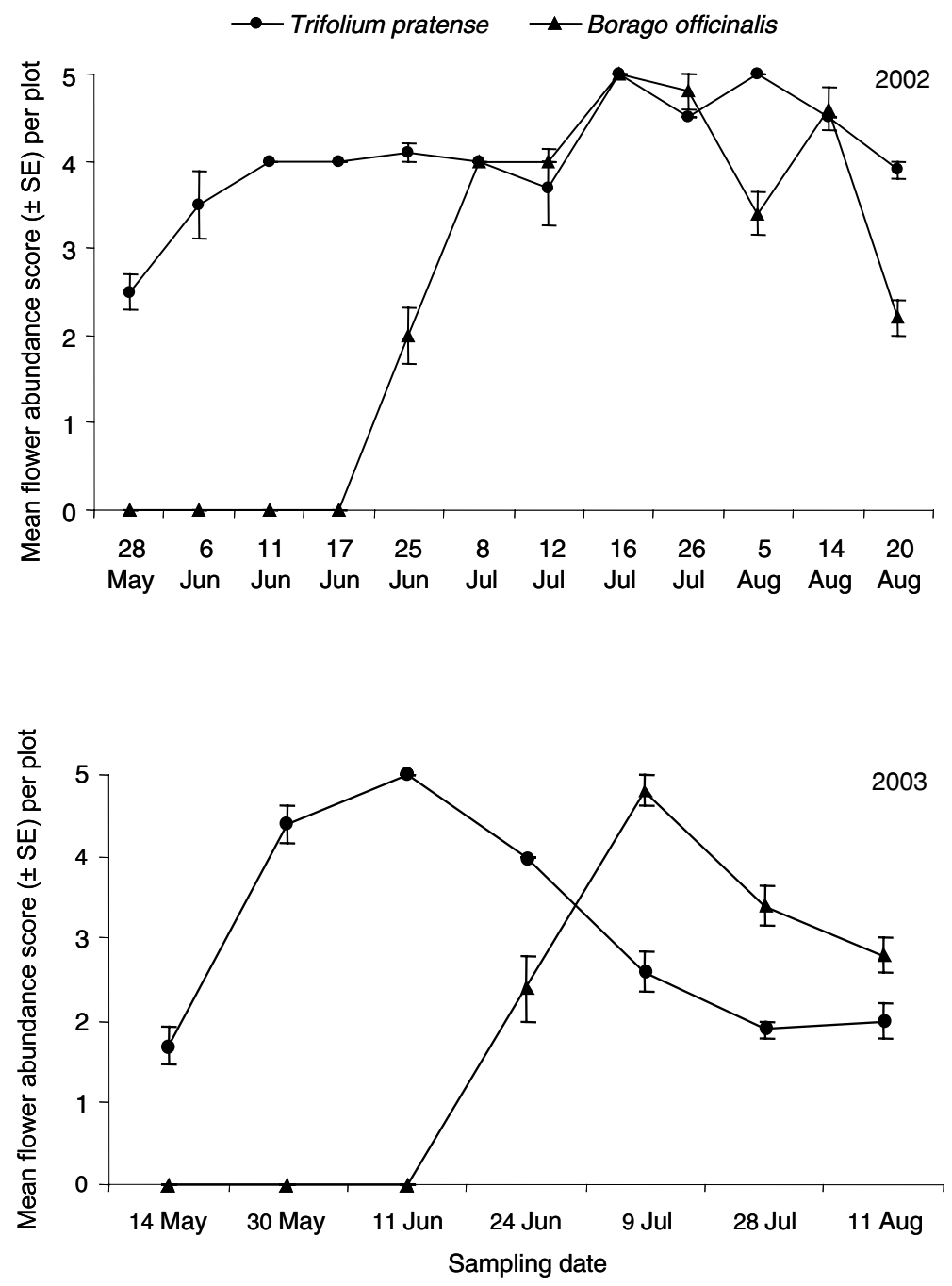

Figure 2. Flowering phenology of red clover, Trifolium pratense (mean of scores from basic and diverse perennial mixtures) and borage, Borago officinalis (scores from annual mixture) in 2002 and 2003.

mixtures as it is likely to develop and prolong the value of this restored habitat for bumblebees (e.g. Carvell et al., 2004). Considering the costs of native wildflower seed, some other species could be excluded from the mix, but a proportion of open-flowered composites (Asteraceae, e.g. Leontodon hispidus) or umbellifers (Apiaceae, e.g. Daucus carota) should remain to provide resources for other social or solitary bees, butterflies and hoverflies (e.g. Feber et al., 1996; Westrich, 1996). In addition, the potential for perennial mixtures or other measures to provide early season forage plants for bumblebee queens has yet to be realised and requires further investigation.

\subsection{Pollen analysis vs direct observation methods}

Differences between the preferred forage plants of B. terrestris and B. pascuorum as identified by direct observation were further 
emphasized by differences in the pollen loads they collected. It is not surprising that most of the pollen types identified were from flower species in the sown mixtures (e.g. B. officinalis and $T$. pratense), as these were the species which bumblebees were visiting when caught (as in Yalden, 1982). Still, this highlights the functional importance of the introduced mixtures in providing forage resources relative to the existing farmed landscape. A high degree of flower constancy during each foraging trip was evident from the many single-species samples, as well as fidelity to the experimental treatments, suggesting that many bumblebees were foraging exclusively on the sown mixtures, at least during the peak of colony activity.

Several plant species from beyond the experimental area were present in the pollen loads, including Papaver rhoeas, Stachys sylvatica and Rubus fruticosus. That these species had been visited was not apparent by direct observation alone. Mapping the locations and flowering times of these species relative to the experimental margin would in future allow us to examine farm-scale movements of bumblebees, based on the pollen types collected by each individual in a foraging trip. Our data also suggest that, in suitable habitats, B. pascuorum may be able to exploit a similarly wide range of plant species for pollen as B. terrestris. Although $B$. terrestris is considered the most polylectic of bumblebee species, this may be primarily an artefact of its high relative abundance throughout much of Europe (Goulson, 2003). That B. pascuorum has the potential to obtain pollen from a wide range of species (although it prefers to specialise on the Fabaceae) may explain why it is one of only two longer-tongued Bombus species remaining common in the UK (Williams, 1982; Goulson, 2003).

\subsection{Conclusions and implications for bumblebee conservation}

The effects of habitat change in many European agricultural landscapes have resulted in bumblebee communities dominated by relatively short-tongued species such as $B$. terrestris and B. lapidarius (Walther-Hellwig and Frankl, 2000; Pywell et al., 2005). These species may well benefit from temporary forage resources such as mass flowering crops, as sug- gested by Westphal et al. (2003), or annually sown mixtures including Borago officinalis, as in this study. However, we argue that these foraging resources alone are not sufficient to conserve the full bumblebee assemblage in agricultural ecosystems. Perennial forage plants such as Trifolium pratense are highly valuable, particularly as pollen sources, for the longtongued species. These bumblebees are required to perform a pollination service that cannot be replaced by short-tongued species or honeybees (Corbet, 2000). Our study provides useful evidence of foraging by long- and shorttongued bumblebee species in habitats created from carefully selected perennial and annual seed mixtures. Further research at a larger scale is now required to fully assess the impacts of introduced foraging habitats on bumblebee populations, rather than simply on the abundance or activity of individuals. In conclusion, we recommend two key factors which should be considered in the design of agri-environmental schemes aiming to conserve bumblebees and other pollinators in agricultural ecosystems: (i) the relative specialisation of different bumblebee species towards certain plant families for nectar and pollen collection, in particular the association of long-tongued species with the Fabaceae, and (ii) the flowering phenology of species chosen as seed mixture components for habitat restoration.

\section{ACKNOWLEDGEMENTS}

This research was funded by a grant from English Nature (Project Ref. CPAU03/03/160). The authors would like to thank David Sheppard for his support, and Dave Goulson, Sarah Corbet, Bernard Vaissière and two anonymous referees for valuable comments on the manuscript. Thanks also to the UK Met Office for permission to quote climatic data.

Résumé - Estimation de la valeur de mélanges de plantes mellifères annuelles et pérennes pour les bourdons par l'observation directe et l'analyse pollinique. En raison du déclin de plusieurs espèces de bourdons (Bombus spp.) en Europe et en Amérique du Nord au cours du $20^{\mathrm{e}}$ siècle, il est nécessaire de disposer de méthodes pour restaurer les habitats adéquats et conserver ces pollinisateurs qui jouent un rôle important dans les écosystèmes agricoles. En Europe les mesures agri-environnementales permettent d'introduire des zones riches en fleurs dans les surfaces de cultures intensives, mais la composition 
et la gestion de ces zones nécessite d'être affinées. Au cours d'une étude de trois ans, nous avons estimé la valeur de trois mélanges de graines fournissant des ressources pour les bourdons : deux mélanges de graminées et de fleurs sauvages (l'une avec 18 plantes herbacées, l'autre avec seulement trois) et un mélange de cultures de protection ressemées chaque année (Tab. I). Nous avons relevé les visites des bourdons et des abeilles domestiques (Apis mellifera) sur les fleurs le long de transects pour chacun des mélanges de mai à août en 2002 et 2003 . Nous avons aussi échantillonné et analysé les pelotes de pollen de Bombus pascuorum et B. terrestris. Cette approche est inhabituelle dans ce genre d'études, mais elle offre des informations importantes en sus de l'observation directe des individus.

Les trois mélanges de plantes ont été diversement visités en fonction de l'espèce de bourdon (Fig. 1 et Tab. I). Les bourdons à langue longue (B. pascuorum et $B$. hortorum) ont préféré les mélanges de plantes pérennes où Trifolium pratense était dominant, tandis que les bourdons à langue courte (B. terrestris/ lucorum et $B$. pratorum) et les abeilles domestiques ont concentré leurs visites sur Borago officinalis dans le mélange annuel; $B$. lapidarius a visité les fleurs des trois mélanges. Les mélanges pérennes ont fourni des plantes de façon plus continue durant toute la saison (Fig. 2, Tabs. II et IV). Les mélanges annuels devraient donc soit être ressemés au cours de la saison, soit comporter une gamme plus large d'espèces pour offrir des ressources aux deux types de bourdons durant toute leur cycle de vie. L'analyse des pelotes de pollen a confirmé les caractéristiques des visites observées directement (Tabs. V et VI). $B$. pascuorum a récolté du pollen sur 13 espèces et, bien que $53 \%$ des pelotes fussent mixtes, $T$. pratense dominait dans la plupart d'entre elles. B. terrestris a récolté du pollen sur 9 plantes, se limitant plus au mélange annuel. $32 \%$ de ses pelotes étaient mixtes mais le pollen de $B$. officinalis était dominant dans nombre d'entre elles. Les deux espèces ont présenté un fort degré de constance florale aux espèces semées, prouvant la valeur fonctionnelle des mélanges de plantes dans le paysage agricole. Les pelotes renfermaient aussi des pollens prélevés sur des plantes en dehors de la zone d'expérimentation.

Nous recommandons que deux facteurs clés soient pris en compte dans la mise en place des mesures agri-environnementales qui visent à préserver les bourdons et les autres pollinisateurs : (i) la spécialisation relative des diverses espèces de bourdons envers certaines familles botaniques pour la récolte du nectar et du pollen, en particulier l' association des bourdons à langue longue avec les fabacées et (ii) la phénologie de la floraison des espèces choisies pour la constitution de mélange aux fins de restauration des habitats.

Bombus / butinage / plante mellifère / mélange / pollen / restauration habitat
Zusammenfassung - Bewertung von Samenmischungen ein- und mehrjähriger Nahrungspflanzen für Hummeln durch direkte Beobachtung und Pollenanalyse. Als Folge des Rückgangs von mehreren Hummelarten in ganz Europa und Nordamerika während des 20 . Jahrhunderts brauchen wir eine Methode zur Wiederbeschaffung geeigneter Habitate, um diese wichtigen Bestäuber im landwirtschaftlichen Ökosystem zu erhalten. In Europa gelingt es oft durch landwirtschaftlich-umweltschützende Maßnahmen mit einer Anlage blütenreicher Flächen inmitten von intensiv genutzten landwirtschaftlichen Flächen. Allerdings benötigt die Zusammensetzung und Bearbeitung solcher Flächen eine weitere Optimierung. Während einer dreijährigen Untersuchung überprüften wir den Wert von 3 Samenmischungen auf Ackerland in England in Bezug auf ihre Bedeutung als Nahrungsquellen für Hummeln (Bombus spp.). Ein entsprechender Versuch wurde mit Mischungen von mehrjährigen Gräsern und Wildblumen durchgeführt (eine mit 18, die andere mit nur 3 Arten), um sie mit bodendeckenden einjährigen Samenpflanzen zu vergleichen (Tab. I). Die Blütenbesuche von Hummeln und Honigbienen wurden bei allen Mischungen entlang von Querlinien zwischen Mai und August im Jahr 2002 und 2003 überwacht. Wir sammelten und analysierten auch die Pollenladungen von Bombus pascuorum und B. terrestris. Solch ein Ansatz wird nicht immer bei Studien über eine Habitatnutzung durch Bienen angewendet, ergibt aber wichtige Zusatzinformationen zur individuellen Beobachtung.

Hummeln zeigten artenabhängig sehr unterschiedliche Verhaltensmuster auf die 3 Pflanzenmischungen (Abb. 1 und Tab. II). Die langzungigen Hummelarten bevorzugten die mehrjährigen, vor allem Trifolium pratense haltigen Mischungen, während die kurzzungigen Hummeln und Honigbienen, Apis mellifera, sich auf Borago officinalis in den einjährigen Mischungen konzentrierten. B. lapidarius beflog Blüten in allen 3 Mischungen. Die mehrjährigen Mischungen boten während der ganzen Saison eine gleichmäßigere Nahrung (Abb. 2, Tab. III und Tab. IV). Demnach sollten die einjährigen Mischungen entweder nacheinander gesät werden oder mehrere Arten enthalten, die auch den Lang- und Kurzzungen-Bienen während der gesamten Lebensdauer der Völker Nahrung anbieten.

Die Sammelmuster an Blüten wurden durch die Analyse der Pollenladungen bestätigt (Tab. V und VI). $B$. pascuorum sammelte Pollen von 13 Arten. Während $53 \%$ der Pollenhöschen gemischt waren, wurden vor allem von $T$. pratense und $B$. terrestris nur Pollen von 9 Arten gesammelt, da sie durch die einjährigen Mischungen eingeengt waren. $32 \%$ der Höschen von $B$. terrestris waren gemischt, aber bei $B$. officinalis dominierte eine Pollensorte in vielen Höschen. Beide Arten zeigten eine hohen Grad von Blütenstetigkeit bei gesäten Arten, ein Zeichen für den funktionellen Wert von Nahrungsmischungen in landwirtschaftlichen Flächen. Die Höschen gaben auch Aufschluss über Nahrungspflanzen außerhalb des Versuchsgebietes. 
Abschließend empfehlen wir die Berücksichtigung von 2 Schlüsselfaktoren bei der Ausgestaltung landwirtschaftlich-umweltschützender Maßnahmen zum Erhalt von Hummeln und anderen Bestäubern: (i) die relative Spezialisierung der verschiedenen Hummelarten auf bestimmte Pflanzenfamilien für Nektar und Pollen, besonders die Verbindung der Langzungenarten mit Fabaceae, und (ii) die Phänologie der Blühzeiten der Pflanzen in den Pflanzenmischungen.

\section{Hummeln / Nahrungsflüge / Pollen / Samenmi- schungen / Restauration}

\section{REFERENCES}

Anasiewicz A., Warakomska Z. (1977) Pollen food of the Bumble-bees (Bombus Latr. Hymenoptera) and their association with the plant species in the Lubin region, Ekol. Pol. 25, 309-322.

Anon (1995) Biodiversity - The UK Steering Group Report. Volume 2 Action Plans. HMSO London, available online at: http://www.ukbap.org.uk/ Library/Tranche1_Ann_f.pdf and http://www. ukbap.org.uk/Library/Tranche1_Ann_g.pdf (accessed on 13 December 2005).

Brian A.D. (1951) The pollen collected by bumblebees, J. Anim. Ecol. 20, 191-194.

Buchmann S.E., Nabhan G.P. (1996) The Forgotten Pollinators, Island Press, Washington DC, USA, 292 p.

Carreck N.L., Williams I.H. (1997) Observations on two commercial flower mixtures as food sources for beneficial insects in the UK, J. Agric. Sci. (Camb.) 128, 397-405.

Carreck N.L., Williams I.H. (2002) Food for insect pollinators on farmland: insect visits to flowers of annual seed mixtures, J. Insect Conserv. 6, 13-23.

Carreck N.L., Williams I.H., Oakley J.N. (1999) Enhancing farmland for insect pollinators using flower mixtures, In Field margins and buffer zones: ecology, management and policy, Asp. Appl. Biol. 54, 101-108.

Carvell C., Meek W.R., Pywell R.F., Nowakowski M. (2004) The response of foraging bumblebees to successional change in newly created arable field margins, Biol. Conserv. 118, 327-339.

Corbet S.A., Williams I.H., Osborne J.L. (1991) Bees and the pollination of crops and wild flowers in the European Community, Bee World 72, 47-59.

Corbet S.A. (2000) Conserving compartments in pollination webs, Conserv. Biol. 14, 1229-1231.

Dias B.S.F., Raw A., Imperatriz-Fonseca V.L. (1999) International Pollinators Initiative: The São Paulo Declaration on Pollinators, Report on the Recommendations of the Workshop on the Conservation and Sustainable Use of Pollinators in Agriculture with Emphasis on Bees. Brasília: Brazilian Ministry of the Environment (MMA) 1999, 66 p.
Engels W., Schulz U., Radle M. (1994) Use of the Tübingen mix for bee pasture in Germany, in: Matheson A. (Ed.), Forage for bees in an agricultural landscape, International Bee Research Association, Cardiff, pp. 57-65.

Feber R.E., Smith H., Macdonald D.W. (1996) The effects on butterfly abundance of the management of uncropped edges of arable fields, J. Appl. Ecol. 33, 1191-1205.

Free J.B. (1993) Insect Pollination of Crops, 2nd ed., Academic Press, London, UK.

Fuller R.M. (1987) The changing extent and conservation interest of lowland grasslands in England and Wales: a review of grassland surveys 1930-84, Biol. Conserv. 40, 281-300.

Fussell M., Corbet S.A. (1992) Flower usage by bumblebees: a basis for forage plant management, J. Appl. Ecol. 29, 451-465.

Goulson D. (2003) Bumblebees: their behaviour and ecology, Oxford University Press, Oxford.

Goulson D., Darvill B. (2004) Niche overlap and diet breadth in bumblebees; are rare species more specialized in their choice of flowers? Apidologie $35,55-64$.

Goulson D., Hanley M.E., Darvill B., Ellis J.S., Knight M.E. (2005) Causes of rarity in bumblebees, Biol. Conserv. 122, 1-8.

Haines-Young R. (Ed.) (2000) Accounting for nature: assessing habitats in the UK countryside, Department of the Environment, Transport and the Regions, London, available online at: http:// www.cs2000.org.uk/report.htm (accessed on 13 December 2005).

Harder L.D. (1985) Morphology as a predictor of flower choice by bumblebees, Ecology 66, 198210.

Kevan P.G. (1991) Pollination: keystone process in sustainable global productivity, Acta Hortic. 288, $103-110$

Kosior A. (1995) Changes in the fauna of bumblebees (Bombus Latr.) and cuckoo-bees (Psithyrus Lep.) of selected regions in southern Poland, in: Banaszak J. (Ed.), Changes in Fauna of Wild Bees in Europe, Pedagogical Univ., Bydgoszcz, Poland, pp. 103-111.

Marshall E.J.P., Moonen A.C. (2002) Field margins in northern Europe: their functions and interactions with agriculture, Agric. Ecosyst. Environ. 89, 5-21.

Meek B., Loxton D., Sparks T., Pywell R., Pickett H., Nowakowski M. (2002) The effect of arable field margin composition on invertebrate biodiversity, Biol. Conserv. 106, 259-271.

Prŷs-Jones O.E., Corbet S.A. (1991) Bumblebees. Naturalists' Handbooks 6, The Richmond Publishing Co. Ltd., Slough.

Pyke G.H. (1982) Local geographic distributions of bumblebees near Crested Butte, Colorado: competition and community structure, Ecology $63,555-573$

Pywell R.F., Warman E.A., Carvell C., Sparks, T.H., Dicks L.V., Bennett D., Wright A., Critchley 
C.N.R., Sherwood A. (2005) Providing foraging resources for bumblebees in intensively farmed landscapes, Biol. Conserv. 121, 479-494.

Ranta E., Lundberg H. (1980) Resource partitioning in bumblebees: the significance of differences in proboscis length, Oikos 35, 298-302.

Rasmont P., Mersch P. (1988) Première estimation de la dérive faunique chez les bourdons de la Belgique (Hymenoptera : Apidae), Ann. Soc. R. Zool. Belg. 118, 141-147.

Smeets P., Duchateau M.J. (2003) Longevity of Bombus terrestris workers (Hymenoptera: Apidae) in relation to pollen availability, in the absence of foraging, Apidologie 34, 333-337.

Stace C. (1999) Field flora of the British Isles, Cambridge University Press, Cambridge, UK.

Stoate C., Szczur J., Aebischer N.J. (2003) Winter use of wild bird cover crops by passerines on farmland in northeast England, Bird Study 50, 15-21.

Svensson B., Lagerlöf J., Svensson Bo. G. (2000) Habitat preferences of nest-seeking bumble bees (Hymenoptera: Apidae) in an agricultural landscape, Agric. Ecosyst. Environ. 77, 247-255.

Walther-Hellwig K., Frankl R. (2000) Foraging habitats and foraging distances of bumblebees,
Bombus spp. (Hym., Apidae) in an agricultural landscape, J. Appl. Entomol. 24, 299-306.

Westphal C., Steffan-Dewenter I., Tscharntke T. (2003) Mass flowering crops enhance pollinator densities at a landscape scale, Ecol. Lett. 6, 961965.

Westrich P. (1996) The problems of partial habitats, in: Matheson A., Buchmann S.L., O'Toole C., Westrich P., Williams I.H. (Eds.), The Conservation of Bees, Linn. Soc. Symp. Ser. 18, Academic Press, London.

Westrich P., Schmidt K. (1986) Methoden und Anwendungsgebiete der Pollenanalyse bei Wildbienen (Hynemoptera, Apoidea), Linzer Biol. Beitr. 18, 341-360.

Williams P.H. (1982) The distribution and decline of British bumblebees (Bombus Latr.), J. Apic. Res. 21, 236-245.

Williams I.H., Christian D.G. (1991) Observations on Phacelia tanacetifolia Bentham (Hydrophyllaceae) as a food plant for honey bees and bumble bees, J. Apic. Res. 30, 3-12.

Yalden P.E. (1982) Pollen collected by the bumblebee Bombus monticola Smith in the Peak District, England. J. Nat. Hist. 16, 823-832. 